\title{
CHANGES IN PEDAGOGICAL ACTIVITY AS A RESULT OF THE INFORMATIZATION OF EDUCATION
}

\author{
Dilnoza Anvarovna Zaripova, \\ Tashkent University of information technology named \\ after Al-Khorazmiy
}

dof http://dx.doi.org/10.26739/2573-5616-2018-3-1-8

\begin{abstract}
This article is devoted to the changes that occurred in pedagogical activity because of informatization. These changes have become a pre-requisite for the innovative activity of the teacher. The author of the article gives comparisons of pedagogical activity with and without ICT.

Key words: pedagogical activity, education, innovation, innovative activity, innovative process, informatization, ICT, untraditional learning system, innovative learning system.

$\mathrm{N}$ ow the world is constantly evolving. Modern people can no longer imagine their life without the results of scientific and technological progress, namely, without innovations, which have already become familiar for society. Most scientists believe that innovation is the main driver of economic and social development. Innovative activity has led the world community to a new, higher stage of development.

"In modern conditions, when the main indicator of the country's competitiveness is increasingly becoming more important than, to a greater extent, the level of education of the population - the most important process of progress," notes Sh.Mirziyoyev. "Sustainable socio-economic progress cannot be imagined without innovative development, broad scientific and technological cooperation and the introduction of new technologies, achievements of science and technology." [1]

Informatization of education is part of the informatization of society, a process that corresponds to information hacking or revolution since the middle of the 20th century, which gives grounds to characterize modern society as information. This means that in all spheres of human activity the role of information processes increases, the need for information and in the means for its production, processing, storage and use increases.

Informatization of education has become a prerequisite for changing the system of education. Innovations have a huge impact on all spheres of human life, including education.
\end{abstract}


Information and communication technology (ICT) is "a broad range of digital technologies used to create, transfer and disseminate information and provide services (computer hardware, software, telephone lines, cell phones, e-mail, cellular and satellite technology, network cable and wireless communications, multimedia, and Internet)".[2]

The term "innovation" comes from the Latin word "inovatio", which in translation means innovation, innovation. The dictionary of philosophical terms gives the following understanding of this term: "Innovation is a cultural phenomenon that did not exist at the previous level of development, but they appeared at this stage and were recognized in it ("socialized"); fixed in sign form and in the activity by changing the methods, mechanisms, results, contents of the activity itself ".[4]

Innovation is the result of the creation of a fundamentally new or modified means (economic, scientific, technical, social and environmental). The goal of innovative activity is a qualitative change in the personality of the student in comparison with the traditional system. The goal of innovative activity is a qualitative change in the personality of the student in comparison with the traditional system.

Development of the ability to motivate actions, self-oriented in the information received, the formation of creative non-conventional thinking, the development of children through access to the disclosure of their natural abilities, using the latest achievements of science and practice.

A comparative traditional pedagogical activity and innovative pedagogical activity with using ICT can draw the following conclusions. (Table 1.)

Table 1.Comparative analysis

\begin{tabular}{|c|c|}
\hline Traditional pedagogical activity & $\begin{array}{l}\text { Innovative pedagogical activity with using } \\
\text { ICT }\end{array}$ \\
\hline Activity of teacher & Activity of teacher \\
\hline \multicolumn{2}{|c|}{ Teacher's position } \\
\hline Main source of knowledge & $\begin{array}{l}\text { Manager } \\
\text { Consultant } \\
\text { Teacher } \\
\text { Designer } \\
\text { Producer }\end{array}$ \\
\hline \multicolumn{2}{|c|}{ Pedagogical tasks } \\
\hline Teaching & $\begin{array}{l}\text { Teaching } \\
\text { Managing } \\
\text { Organizing } \\
\text { Increasing self-study }\end{array}$ \\
\hline \multicolumn{2}{|c|}{ Aims } \\
\hline $\begin{array}{l}\text { Forming the: } \\
\text { Knowledge } \\
\text { Skills } \\
\text { Abilities }\end{array}$ & $\begin{array}{l}\text { Forming the: } \\
\text { Knowledge } \\
\text { Skills } \\
\text { Abilities } \\
\text { Competences }\end{array}$ \\
\hline
\end{tabular}




\begin{tabular}{|c|c|}
\hline \multicolumn{2}{|c|}{ Forms of teaching } \\
\hline Frontal & $\begin{array}{l}\text { Interactive, working in small groups } \\
\text { Conventional-passive interaction } \\
\text { Active interaction } \\
\text { Researching forms }\end{array}$ \\
\hline \multicolumn{2}{|c|}{ Teaching methods } \\
\hline $\begin{array}{l}\text { Lecture } \\
\text { Explanation } \\
\text { Instruction } \\
\text { Demonstration } \\
\text { Verbal } \\
\text { Questinary }\end{array}$ & $\begin{array}{l}\text { Interaction } \\
\text { Video lecture } \\
\text { Multimedia projects } \\
\text { Teaching in: } \\
\text { - MOODLE } \\
\text {-Internet } \\
\text {-Email } \\
\text {-ICT. }\end{array}$ \\
\hline \multicolumn{2}{|c|}{ Means } \\
\hline $\begin{array}{l}\text { Textbook } \\
\text { Training manual } \\
\text { Handout material } \\
\text { Instruments: } \\
\text {-Overhead projector } \\
\text {-Layout } \\
\text {-Diagram }\end{array}$ & $\begin{array}{l}\text { Computer } \\
\text { Multimedia projects } \\
\text { IP Board } \\
\text { IPad } \\
\text { E-book } \\
\text { Cloud technology } \\
\text { Moodle SMART room } \\
\text { Virtual lab } \\
\text { E-library }\end{array}$ \\
\hline \multicolumn{2}{|c|}{ Self-study } \\
\hline $\begin{array}{l}\text { Essay } \\
\text { Course paper }\end{array}$ & $\begin{array}{l}\text { Essay } \\
\text { Course paper } \\
\text { Projects }\end{array}$ \\
\hline \multicolumn{2}{|c|}{ Assessment } \\
\hline Test, verbal, in wring & $\begin{array}{l}\text { Test, verbal, in wring, e-tests (nonstandard } \\
\text { tests) e-portfolio, assessment. }\end{array}$ \\
\hline \multicolumn{2}{|c|}{ Expected result } \\
\hline Formed knowledge, skills, abilities & $\begin{array}{l}\text { Formed knowledge, skills, abilities, } \\
\text { competences. }\end{array}$ \\
\hline
\end{tabular}

As can be seen from the table, innovations are aimed at improving the education process and other areas of the society. Innovations arise as a result of attempts to solve a traditional problem in a new way, as a result of a long process of accumulation and comprehension of facts, when a new quality is born that has an innovative meaning. Most modern innovations are in continuity with historical experience and have analogs in the past.

In other words, innovations are such topically important and systemically self-organizing new growths that arise based on a variety of initiatives and innovations that are promising for the evolution of education and positively influence its developing, as well as the development of a wider education space.

This gives grounds to assert that the innovation process is a motivated, purposeful and conscious process for creating, mastering, using and 
disseminating modern (or modernized) ideas (theories, techniques, technologies, etc.) that are relevant and adapted for these conditions and corresponding to certain criteria. It is aimed at a qualitative improvement of the system in which innovation is introduced, and involves stimulating its partici pants and changing their views from the perspective of innovation.

Using innovations, I concluded that in today's environment the use of computer allows to expand the boundaries of the lesson. A new system of work with illustrative material is being created, the possibility of reducing it to a single format. There are new options for the use of seemingly traditional forms. The students themselves are actively working in this direction, they create more presentations, protect your essays and research papers using the computer. Relief of physical activity of the teacher. Instead of a pile of magazines and books with small, not always clear and therefore not all prominent illustrations, instead of a tape recorder and cassettes teacher comes to class with a disc or flash card.

\section{References}

1. Mirzieev Sh.M. The opening speech of the 43rd session of the Council of Foreign Ministers of the Organization of Islamic Cooperation on October 18, 2016 in Tashkent.

2. http://edu-lider.ru/chto-takoe-ikt-2/

3. Azizhjoz Auseva NN Pedagogical technologies and pedagogical skills. Educational manual. -T.: Publishing house of the Writers' Union of Uzbekistan. 2006, 160 p.

4. Dictionary of philosophical terms. - 2 nd ed., Ext. and corrected. - Kemerovo, 2011, 255 with. 